\title{
MIR124-1 Gene
}

National Cancer Institute

\section{Source}

National Cancer Institute. MIR124-1 Gene. NCI Thesaurus. Code C80723.

This gene is involved in the regulation of gene expression and plays a tumor suppressor

role in lung, colorectal and breast carcinomas, leukemia, medulloblastoma and glioblastoma multiforme. 